Study of metal distributions in $\mathrm{YBa}_{2} \mathrm{Cu}_{3} \mathrm{O}_{7-x} / \mathrm{Ag}_{2} \mathrm{O}$ composites

This article has been downloaded from IOPscience. Please scroll down to see the full text article.

1998 Supercond. Sci. Technol. 11558

(http://iopscience.iop.org/0953-2048/11/6/003)

View the table of contents for this issue, or go to the journal homepage for more

Download details:

IP Address: 134.153.186.189

The article was downloaded on 05/03/2013 at 12:15

Please note that terms and conditions apply. 


\title{
Study of metal distributions in $\mathrm{YBa}_{2} \mathrm{Cu}_{3} \mathrm{O}_{7-x} / \mathrm{Ag}_{2} \mathrm{O}$ composites
}

\author{
M Faiz $\nmid$, M Ahmed $\ddagger$, N M Hamdan $\dagger$, Kh A Ziq $\dagger$ and J Shirokoff $\ddagger$ \\ $\dagger$ Department of Physics, King Fahd University of Petroleum and Minerals, Dhahran \\ $\ddagger$ Research Institute, King Fahd University of Petroleum and Minerals, Dhahran \\ 31261, Saudi Arabia
}

Received 3 October 1997, in final form 4 March 1998

\begin{abstract}
The micro proton-induced $x$-ray emission technique has been used to study the elemental distribution profiles of $\mathrm{YBa}_{2} \mathrm{Cu}_{3} \mathrm{O}_{7-x} / \mathrm{Ag}_{2} \mathrm{O}$ high- $T_{c}$ composites on varying the $\mathrm{Ag}_{2} \mathrm{O}$ content. Measurements revealed that $\mathrm{Ag}$ agglomeration starts to appear in samples with $\geq 25 \mathrm{wt} \% \mathrm{Ag}_{2} \mathrm{O}$, becoming prominent at $50 \mathrm{wt} \%$. These results are further supported by $x$-ray diffraction (XRD) measurements performed on the same samples. The XRD results identified a crystalline Ag phase to be present in all of the samples (7-50 wt\% $\mathrm{Ag}_{2} \mathrm{O}$ ), a crystalline $\mathrm{Ag}_{2} \mathrm{O}$ phase in the 25 and $50 \mathrm{wt} \% \mathrm{Ag}_{2} \mathrm{O}$ samples and no evidence for $\mathrm{Ag}$ replacing $\mathrm{Cu}$ or orthogonal-to-tetragonal transformation.
\end{abstract}

\section{Introduction}

Practical applications of high-temperature superconductors (HTSCs) demand superb mechanical as well as superconducting properties. Mechanical properties of $\mathrm{YBa}_{2} \mathrm{Cu}_{3} \mathrm{O}_{7-x}$ (Y123) are generally poor because of low ductility [1-3]. Although adding silver may slightly decrease the critical temperature, it increases the critical current density, reduces the normal-state resistivity [4] and improves the mechanical properties of HTSCs [5-8]. Silver has also been used as a cladding material for shaping HTSC ceramics into wires and tapes [7-9] and has been found to enhance crystal growth at the interface between grains of Bi2212 and Ag casing [10]. Grain boundaries of Y123 not only act as possible sources for mechanical failure but also are responsible for its low critical current density [11]. The addition of a small amount of $\mathrm{Ag}$ seems to enhance the grain growth of Y123 in Y123/Ag composites [12,13] and to improve superconducting properties. However, as the $\mathrm{Ag}$ content increases, more Ag inclusions become interconnected and the grain growth kinetics slows down significantly [13]. It is of great practical importance to determine these critical Ag concentrations above which deteriorating effects become dominant. These effects can clearly be seen in micro proton-induced $\mathrm{x}$-ray emission (PIXE) elemental composition analysis. The PIXE technique can provide information very rapidly on elemental distribution and concentrations with parts per million sensitivity. Only a few applications of PIXE for HTSC characterization have so far been reported in the literature [14-16]. In addition to average composition analysis, elemental distribution profiles can be very important in understanding microscopic variations in the properties of HTSC. These elemental distribution maps can be generated using a focused scanning proton microbeam [16]. In this study, samples of Y123 with different amounts of $\operatorname{Ag}_{2} \mathrm{O}$ addition are analysed by the micro-PIXE and $\mathrm{x}$-ray diffraction (XRD) techniques, in an effort to relate the effects of $\mathrm{Ag}_{2} \mathrm{O}$ distribution and the superconducting properties of $\mathrm{Y} 123 / \mathrm{Ag}_{2} \mathrm{O}$ composites.

\section{Experimental details}

Y123 powder was prepared by solid-state reaction of the constituent oxides mixed in appropriate proportions. The $\mathrm{Y} 123 / \mathrm{Ag}_{2} \mathrm{O}$ composites were prepared by grinding various weight ratios of $\mathrm{Ag}_{2} \mathrm{O}$ (99\% purity) with high-quality polycrystalline $\mathrm{YBa}_{2} \mathrm{Cu}_{3} \mathrm{O}_{6.9}\left(T_{c} \sim 92 \mathrm{~K}, \Delta T \sim 1 \mathrm{~K}\right)$ and sintering at $950{ }^{\circ} \mathrm{C}$ in an oxygen atmosphere for at least $18 \mathrm{~h}$. The samples were cooled down to room temperature at a rate of $5-10^{\circ} \mathrm{C} \mathrm{min}^{-1}$ with intermediate annealing at $500-600{ }^{\circ} \mathrm{C}$ in an oxygen atmosphere. The grinding and annealing processes were repeated to ensure random distribution of the $\mathrm{Ag}_{2} \mathrm{O}$ powder. In this way, $\mathrm{Y} 123 / \mathrm{Ag}_{2} \mathrm{O}$ composites with starting $\mathrm{Ag}_{2} \mathrm{O}$ concentrations of 7, 10, 14, 25 and $50 \mathrm{wt} \%$ were obtained. The critical temperatures of these samples and pure Y123 (0 wt\% Ag) were determined by a standard four-probe technique, using a constant-current source and a Keithly-181 nanovoltmeter. XRD patterns were obtained from the samples using a Phillips PW1700 automated diffractometer with monochromator and spinner operating. The diffraction patterns were generated on a vertical goniometer attached to a broad-focus $\mathrm{x}$-ray tube with copper target energized to $40 \mathrm{kV}$ and $40 \mathrm{~mA}$. The analysis is computer assisted so that the interplanar spacing values can be corrected for the instrument error function by analysing a silicon standard and subsequent phase identification can be carried out. The samples were then 


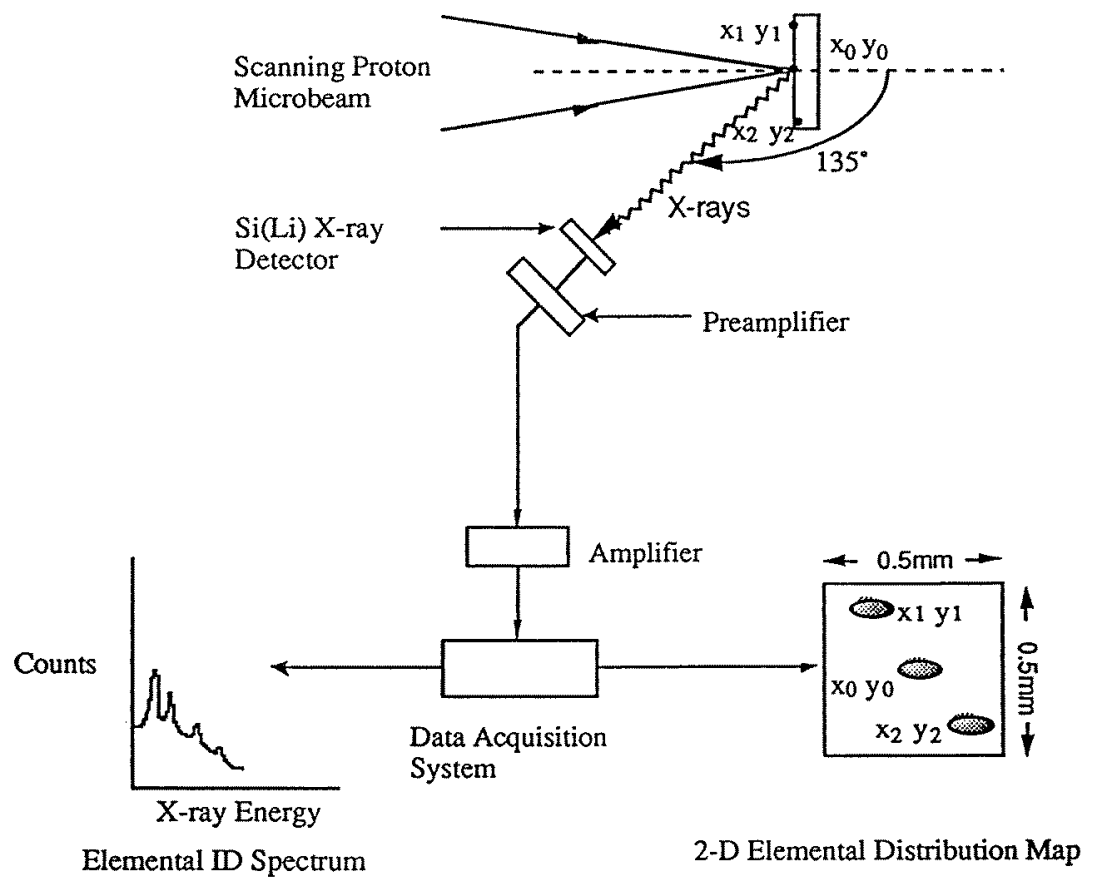

Figure 1. Schematic of the micro-PIXE setup.

analysed using the scanning microbeam facility available in the Tandetron Accelerator Laboratory at the Energy Resources Division of the Research Institute, KFUPM. A detailed description of the facility has been reported elsewhere [17]. The micro-PIXE setup is shown in figure 1. A $2.5 \mathrm{MeV}$ focused proton beam of about $4 \mu \mathrm{m}$ resolution was used to scan an area of $500 \mu \mathrm{m} \times 500 \mu \mathrm{m}$ at a time on the sample surface. The microbeam current was kept low (typically about $30 \mathrm{pA}$ ) to avoid any damage due to heating up of the sample. From each scanned area, an average elemental composition spectrum and several two-dimensional elemental distribution maps were acquired simultaneously.

\section{Results and discussion}

The samples used in this investigation were first characterized by monitoring their resistance as a function of temperature using a four-point contact method. Samples with $\leq 14$ wt $\% \quad \mathrm{Ag}_{2} \mathrm{O}$ have a zero-resistance transition temperature above $90 \mathrm{~K}$. For samples with >14 wt $\%$ $\mathrm{Ag}_{2} \mathrm{O}$, the transition temperature dropped rapidly and the transition width increased with increasing $\mathrm{Ag}_{2} \mathrm{O}$ content. The variation of the zero-resistance transition temperature with $\mathrm{Ag}_{2} \mathrm{O}$ content is shown in figure 2 .

The XRD patterns for all the samples, shown in figure 3 , confirm that they are all single phase with orthorhombic symmetry. Further XRD indexing and refinement was performed using the Powder Diffraction Package (PDP) program [18]. The lattice parameters show very little deviation from those of the standard pure Y123 orthorhombic cell. The observed variations in the lattice parameters with Ag content are shown in figure 4 . These variations reflect different residual stress

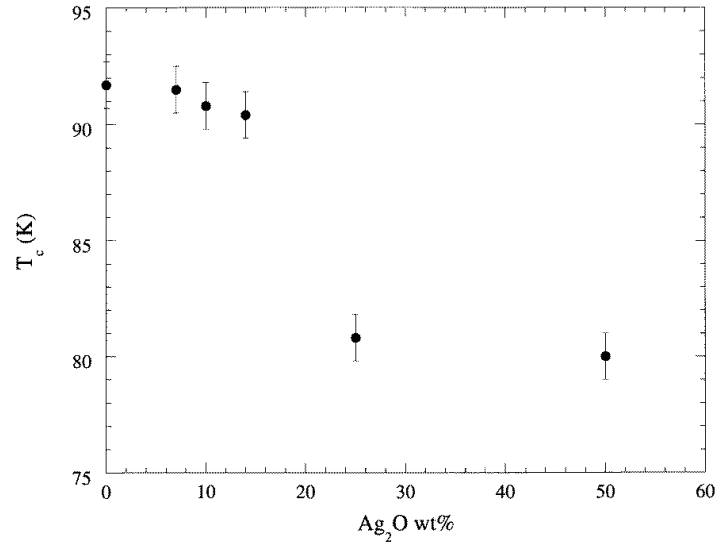

Figure 2. Variation of $T_{c}$ with $\mathrm{Ag}_{2} \mathrm{O}$ content.

values as a result of silver oxide addition [19]. The observed decrease in $T_{c}$ with $\mathrm{Ag}_{2} \mathrm{O}$ addition, seen in figure 2, may be caused by the change in residual stress, oxygen content and disorder in the oxygen sublattice. In addition, in $\mathrm{Y} 123 / \mathrm{Ag}_{2} \mathrm{O}$ composites, superconductormetal-superconductor Josephson junctions formed by the Ag agglomeration (discussed later) between Y123 grains may also affect the value of transition temperature at zero resistance. This is supported by the long tail of resistivity versus temperature curve observed in 25 and $50 \mathrm{wt} \%$ $\mathrm{Ag}_{2} \mathrm{O}$ samples [4,20]. For all composite samples the XRD patterns clearly identify two Ag peaks, (200) and (220) reflections, at $2 \theta=44.2^{\circ}$ and $64.2^{\circ}$ respectively, indicating the presence of $\mathrm{Ag}$ as a separate phase and not replacing the constituents of Y123 [4,21]. Since the (111) reflection of $\mathrm{Ag}_{2} \mathrm{O}$, which is known to have the highest 


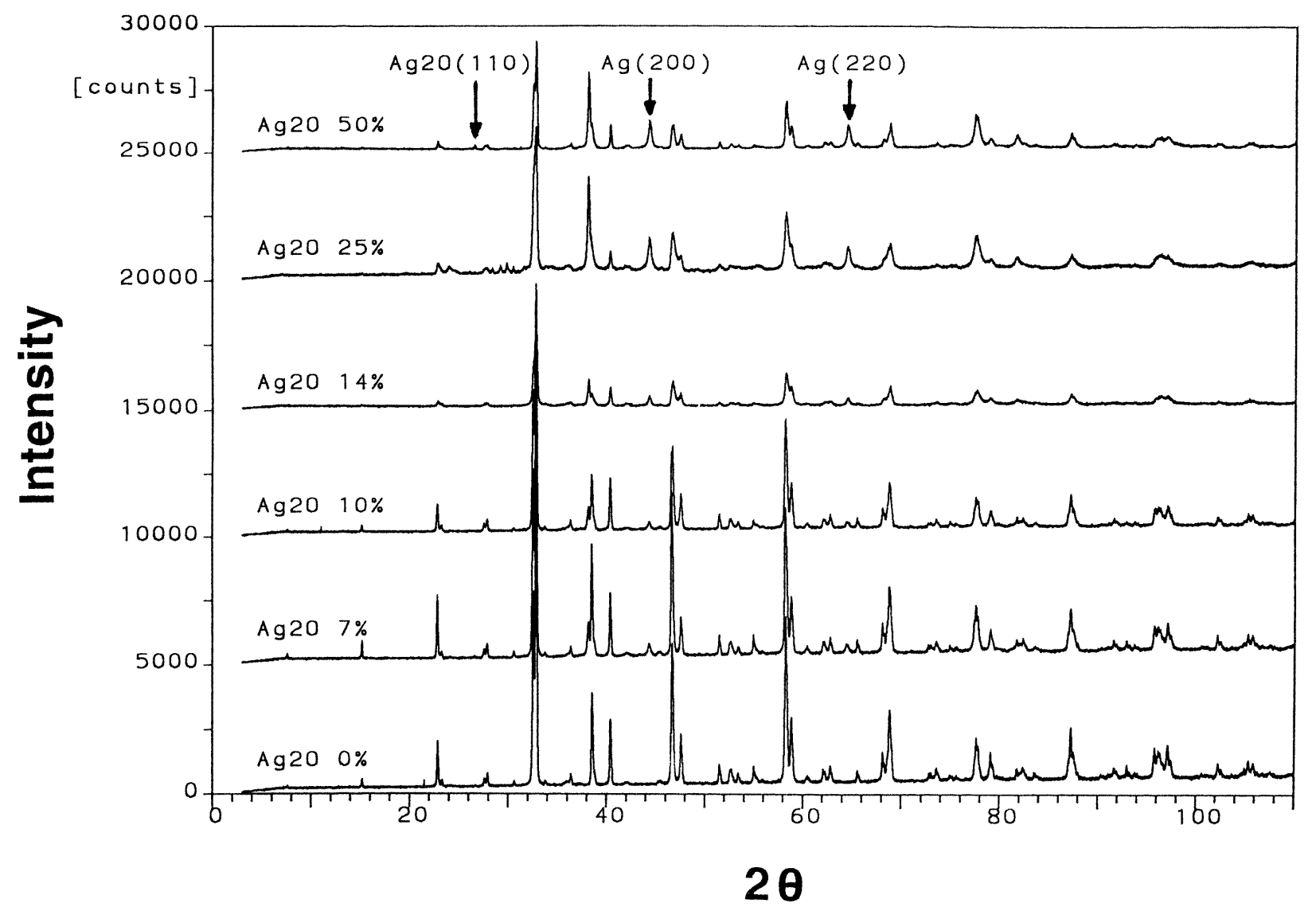

Figure 3. XRD patterns of $\mathrm{Y} 123$ with increasing amounts of $\mathrm{Ag}_{2} \mathrm{O}$. The $\mathrm{x}$-ray patterns are vertically offset by 5000 counts from each other.

intensity, overlaps with the (103) and (111) reflections of Y123 orthorhombic cell, the (110) reflection of $\mathrm{Ag}_{2} \mathrm{O}$ has been used to identify the $\mathrm{Ag}_{2} \mathrm{O}$ phase. The (110) reflection of $\mathrm{Ag}_{2} \mathrm{O}$ at $2 \theta=26.67^{\circ}$ is clearly seen in the diffraction pattern of the sample with $50 \mathrm{wt} \% \mathrm{Ag}_{2} \mathrm{O}$, indicating that the excess silver oxide remains in a separate phase and has not been decomposed to $\mathrm{Ag}$ and $\mathrm{O}$. Nevertheless, a trace of the (110) reflection of $\mathrm{Ag}_{2} \mathrm{O}\left(I_{25} / I_{50}<0.25\right)$ is observed in the $25 \mathrm{wt} \% \mathrm{Ag}_{2} \mathrm{O}$ sample.

Silver addition affects superconducting and magnetic properties, such as critical current density $J_{c}$ and pinning force. Recently, it has been found that scaling of pinning force continues up to about $14 \mathrm{wt} \%$ of $\mathrm{Ag}_{2} \mathrm{O}$. Above such $\mathrm{Ag}$ concentrations, gradual deterioration of magnetic and scaling behaviour has been observed [22]. The sample with $50 \mathrm{wt} \% \mathrm{Ag}_{2} \mathrm{O}$ is drastically degraded.

To look at the distributions of $\mathrm{Ag}$ and other elements in the composite samples, we performed micro-PIXE analysis. Figure 5 shows a typical $x$-ray energy spectrum for the sample with $50 \mathrm{wt} \% \quad \mathrm{Ag}_{2} \mathrm{O}$ showing traces of $\mathrm{Cr}$ and $\mathrm{Fe}$, estimated to be at ppm level, as impurities which might have originated from the $\mathrm{Ag}_{2} \mathrm{O}$. Note that XRD did not detect these impurities because of the very low concentrations. Figure 6 shows the Ag distribution maps for all six samples. It can be seen from the distribution maps that $\mathrm{Ag}$ is uniformly distributed in samples with $\mathrm{Ag}_{2} \mathrm{O}$ up to

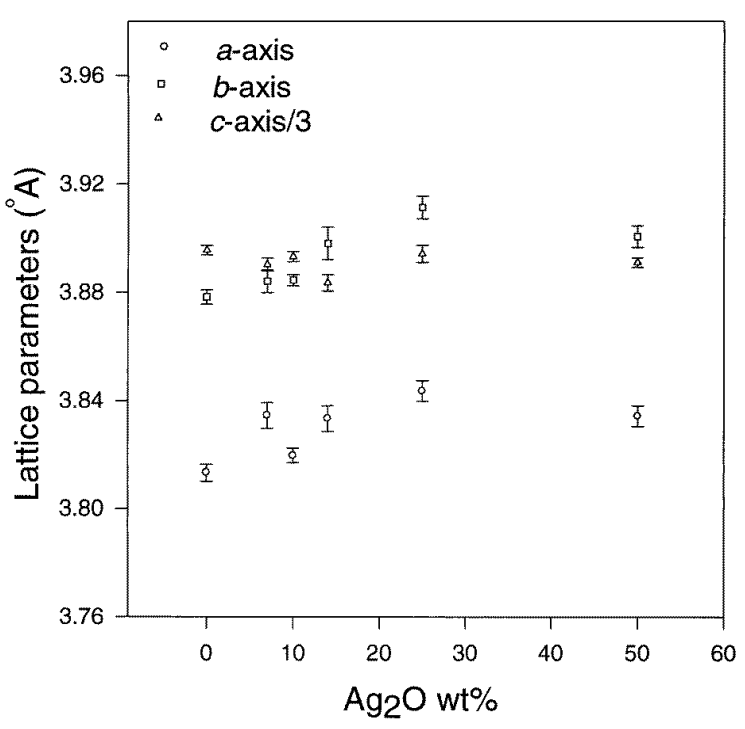

Figure 4. Variation of lattice parameters of $\mathrm{Y} 123$ with $\mathrm{Ag}_{2} \mathrm{O}$ content.

$14 \mathrm{wt} \%$. Agglomeration starts to appear in the sample with $25 \mathrm{wt} \% \mathrm{Ag}_{2} \mathrm{O}$, becoming most prominent in the $50 \mathrm{wt} \%$ $\mathrm{Ag}_{2} \mathrm{O}$ sample. These results not only are consistent with the 


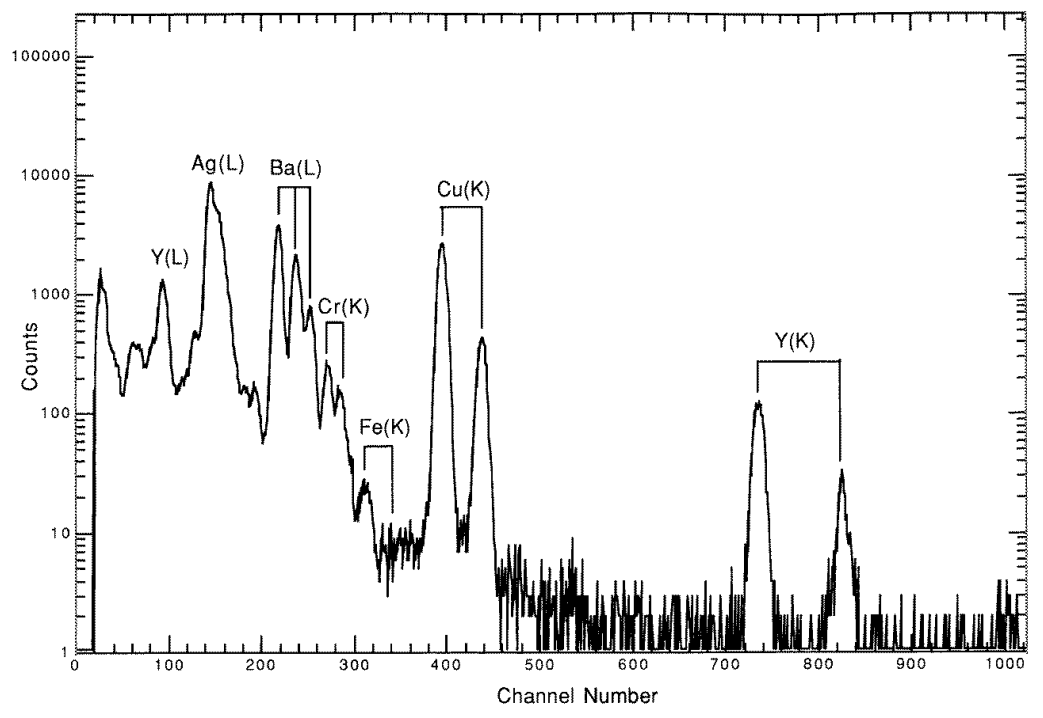

Figure 5. A typical PIXE spectrum for the $\mathrm{Y} 123$ sample with $50 \mathrm{wt} \% \mathrm{Ag}_{2} \mathrm{O}$.

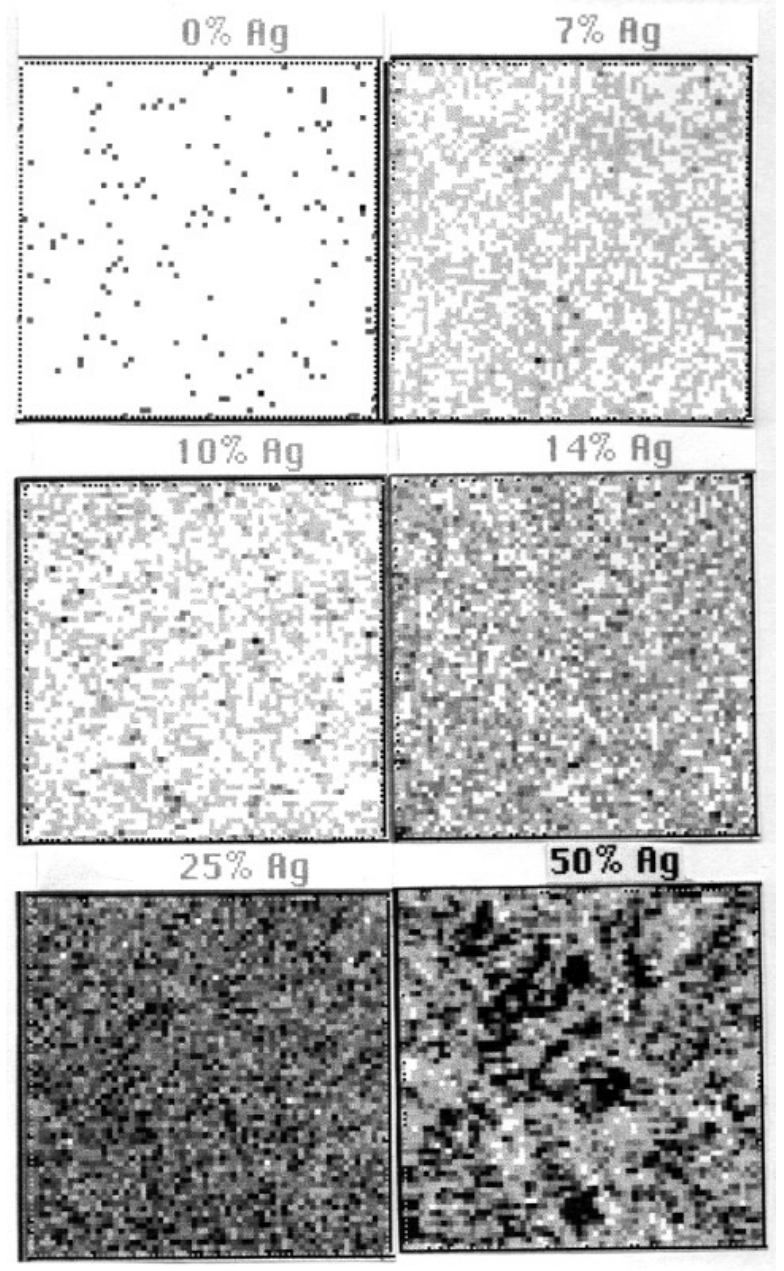

Figure 6. Ag distribution maps for the $\mathrm{Y} 123 / \mathrm{Ag}_{2} \mathrm{O}$ composites.

observations mentioned earlier but also help to explain why superconducting and magnetic properties of $\mathrm{Y} 123 / \mathrm{Ag}_{2} \mathrm{O}$

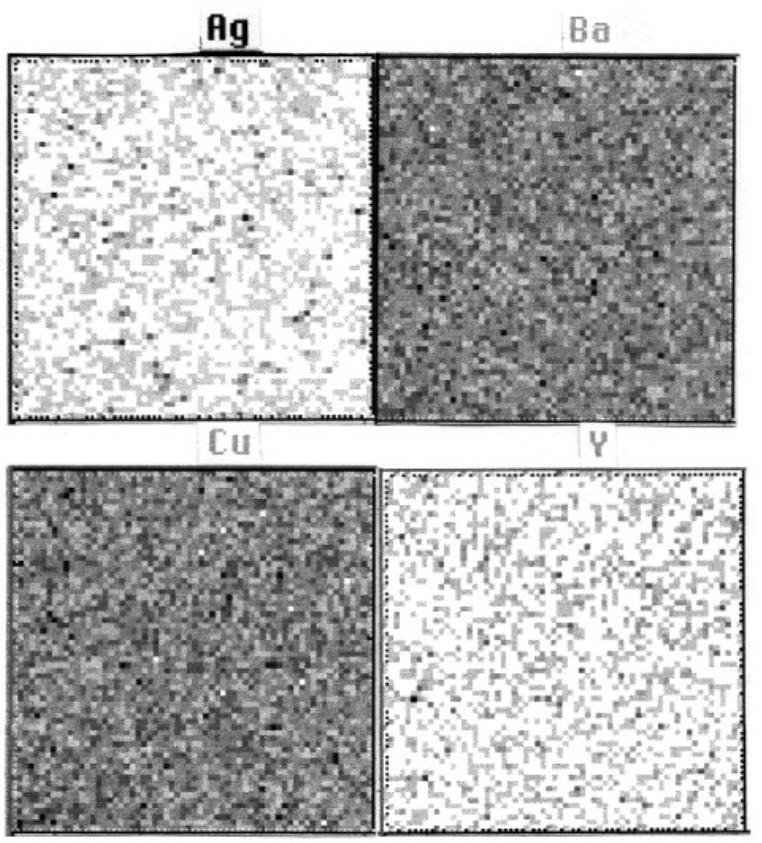

Figure 7. Elemental distribution maps for the $\mathrm{Y} 123$ sample with 10 wt\% $\mathrm{Ag}_{2} \mathrm{O}$.

composite become poor at high $\mathrm{Ag}_{2} \mathrm{O}$ loading. Elemental distribution maps for $10 \mathrm{wt} \%$ and $50 \mathrm{wt} \% \mathrm{Ag}_{2} \mathrm{O}$ samples are shown in figure 7 and figure 8 , respectively. For the $10 \mathrm{wt} \% \mathrm{Ag}_{2} \mathrm{O}$ sample, the distributions of $\mathrm{Ag}, \mathrm{Ba}, \mathrm{Cu}$ and $\mathrm{Y}$ are all uniform. However, for the $50 \mathrm{wt} \% \mathrm{Ag}_{2} \mathrm{O}$ sample, the excess Ag appears to agglomerate in the interface regions between Y123 grains. This result supports the results of Tuan and $\mathrm{Wu}$ [13], mentioned in section 1. The above results are consistent with our XRD observations that $\mathrm{Ag}$ exists as a separate phase in all samples prepared with $\mathrm{Ag}_{2} \mathrm{O}$ precursor and $\mathrm{Ag}_{2} \mathrm{O}$ phase in the samples with 25 and $50 \mathrm{wt} \% \mathrm{Ag}_{2} \mathrm{O}$. 

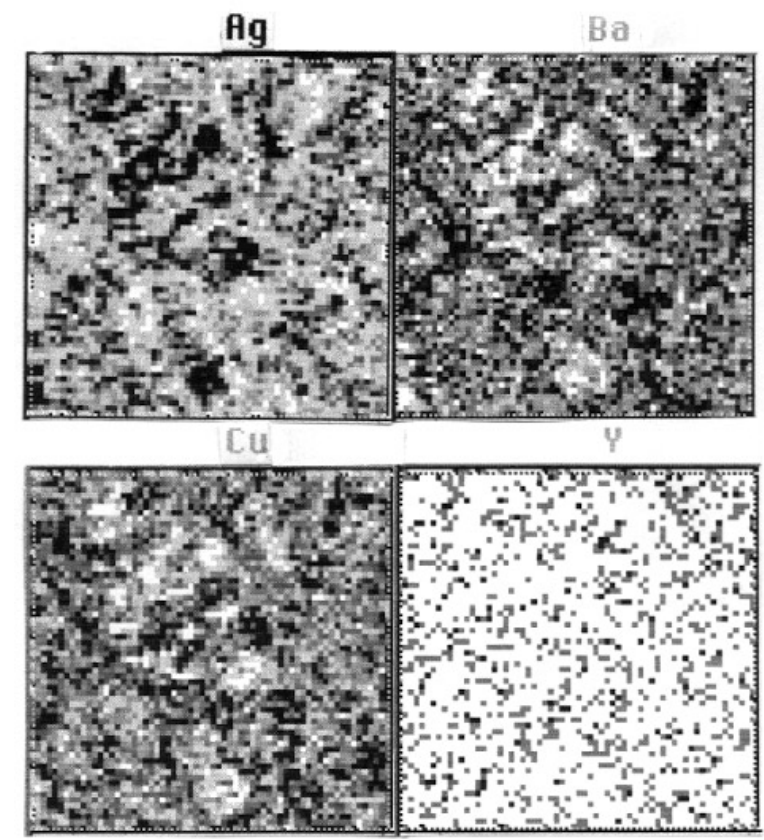

Figure 8. Elemental distribution maps for the $\mathrm{Y} 123$ sample with $50 \mathrm{wt} \% \mathrm{Ag}_{2} \mathrm{O}$.

\section{Conclusion}

In summary, our micro-PIXE results show that $\mathrm{Ag}$ agglomeration starts to appear in the $25 \mathrm{wt} \% \mathrm{Ag}_{2} \mathrm{O}$ sample and it is most prominent when $\mathrm{Ag}_{2} \mathrm{O}$ is increased to $50 \mathrm{wt} \%$, which segregates the Y123 grains. This might contribute to the deterioration of certain superconducting and magnetic properties of these composites above $14 \mathrm{wt} \% \mathrm{Ag}_{2} \mathrm{O}$ loading. These findings are consistent with the XRD results from the $\mathrm{Y} 123 / \mathrm{Ag}_{2} \mathrm{O}$ composites which reveal (i) no evidence for $\mathrm{Ag}$ replacing $\mathrm{Cu}$ in the $\mathrm{Y} 123$ phase, (ii) a crystalline $\mathrm{Ag}$ phase to be present in all of the samples prepared with $\operatorname{Ag}_{2} \mathrm{O}$, (iii) a crystalline $\mathrm{Ag}_{2} \mathrm{O}$ phase to be present in the 25 and $50 \mathrm{wt} \% \mathrm{Ag}_{2} \mathrm{O}$ samples and (iv) no indication of orthogonalto-tetragonal structural phase transition occurring.

\section{Acknowledgments}

The authors acknowledge the support provided by the Physics Department and the Research Institute of King Fahd University of Petroleum and Minerals at Dhahran, Saudi Arabia for this study. Special thanks are given to
S Madhusoodhanan Pillai, Tandetron Accelerator Operator, for technical assistance.

\section{References}

[1] Cook R F, Dinger T R and Clark D R 1987 Appl. Phys. Lett. 51454

[2] Cook R F, Shaw T M and Duncombe P R 1987 Adv. Ceram. Mater. 2606

[3] Alford McN, Birchall J D, Clegg W J, Harmer M A, Kendall K and Jones D H 1988 J. Mater. Sci. 23761

[4] Abdelhadi M 1993 MS Thesis Department of Physics, King Fahd University of Petroleum and Minerals

[5] Pavuna D, Berger H, Tholence J L, Affronte M, Sanjines R, Dubas A, Bugnon P and Vasey F 1988 Physica C 153-155 1339

[6] Singh J P, Shi D and Capone D W 1988 Appl. Phys. Lett. 53237

[7] Matsumuro A, Kasumi K, Mizutani U and Senoo M 1991 J. Mater. Sci. 26737

[8] Ozkan H, Albiss B A, Hamdan N and Menerad A 1994 J. Supercond. 7885

[9] Zannella S, Martini L, Ottobani V, Parmigiani F, Ricca A M and Ripamonti G 1989 Physica C 162-164 1179

[10] Finnemore D K, Ming Xu, Kouzoudis D, Bloomer T, Kramer J, Mckernan S, Balachandran U and Haldar P 1996 Appl. Phys. Lett. 68556

[11] Clarke D R, Shaw T M and Dimos D 1989 J. Amer. Ceram. Soc. 721103

[12] Tiefel T H, Jin S, Sherwood R C, David M E, Kammlott G W, Gallagher P K, Johnson D W Jr, Fastnacht R A and Rhodes W W 1989 Mater. Lett. 7363

[13] Tuan W H and Wu J M 1993 J. Mater. Sci. 281409

[14] Ishii A and Nakamura K 1993 Nucl. Instrum. Methods B 75388

[15] Sandrik R 1994 Nucl. Instrum. Methods B 85154

[16] Faiz M, Ahmed M and Al-Ohali M A 1996 Nucl. Instrum. Methods B 114138

[17] Ahmed M, Nickel J, Hallak A, Abdel-Aal R, Coban A, Al-Juwair H and Aldaous M 1993 Nucl. Instrum. Methods B 82584

[18] Calligaris M and Gevemia S 1990 Department of Chemistry, University of Trieste, personal communication

[19] Ziq Kh A, Hamdan N M and Shirokoff J 1994 Physica C 235-240 1217

[20] Dubson M A, Herbert S T, Calabrese J J, Harris D C, Patton B R and Garland J C 1988 Phys. Rev. Lett. 60 1061

[21] Ganapathi L, Kumar A and Narayan J 1990 Mater. Res. Soc. Symp. Proc. 1691267

[22] Hafidh E A 1996 MS Thesis Department of Physics, King Fahd University of Petroleum and Minerals and references therein 